\title{
Specific Peptide-Bond Cleavage by Microwave Irradiation in Weak Acid Solution
}

\author{
Chi-Yue Wu, ${ }^{1}$ Shui-Tein Chen, ${ }^{1}$ Shyh-Horng Chiou, ${ }^{1,2}$ and Kung-Tsung Wang,
}

Received August 8, 1991

A rapid and selective peptide-bond cleavage in weak acid, induced by microwave irradiation, has been developed. The specific cleavage sites of peptide bonds located only at the carboxyl. and amino-terminal ends of aspartyl residues along the peptide chain. A systematic study including the time course for the cleavage of various aspartyl-containing peptides, the effect of the acidity of the reaction solution on the completeness of peptide-bond cleavage, and the relationship between the power of microwave irradiation and the reaction time of cleavage are studied.

KEY WORDS: Specific cleavage; peptide hydrolysis; microwave irradiation; rate enhancement; weak acid hydrolysis; aspartyl residues.

\section{INTRODUCTION}

Recently, there has been growing interest in applying microwave heating to the rapid thermal digestion prior to elemental and chemical analysis of inorganic and biological samples (Nadkarni, 1984; Fischer, 1986; Fernando et al., 1986; Kingston and Jassie, 1986). The rapid heating capability of the microwave oven leads to a considerable saving in dissolution time, which may eventually replace some of the conventional flame and hot-plate heating protocols. During the last few years, we have introduced a rapid method of microwave heating for the facile preparation of protein and peptide hydrolysates prior to amino acid analysis (Chen et al., 1987; Yu et al., 1988; Chiou and Wang, 1989). Microwave irradiation has also been applied to several organic reactions in a continuous-flow process by which preparative-scale samples may be synthesized with ease using a kitchen microwave oven (Chen et al., 1990).

Previously, partial hydrolysis of proteins in acidic or basic media by coventional heating has been

\footnotetext{
Institute of Biochemical Sciences, National Tajwan University and Institute of Biological Chemistry, Academia Sinica, P.O. Box 23-106, Taipei, Taiwan.

${ }^{2}$ To whom all correspondence should be addressed.
}

reported (Schultz et al., 1962; Tsung and FrankelConrat, 1965; Schultz, 1967; Inglis, 1983; Marcus, 1985; Piszkiewicz et al., 1970; Light, 1967). The protocols are usually laborious and time-consuming. We report here a novel application of microwave technology to the specific cleavage of peptide bonds only at the aspartyl residues (Asp and Asn). The new chemical cleavage can circumvent the inherent contamination problems associated with the microscale structural analysis of peptides and proteins using some proteolytic enzymes.

\section{MATERIALS AND METHODS}

\subsection{Apparatus, Chemicals, and Reaction Vessels}

Custom-made Teflon vials and Teflon-Pyrex reusable hydrolysis tubes (Chiou and Wang, 1990; Wang et al., 1991) were purchased locally (The Continuity Enterprise, Taipei, Taiwan). Each vial can contain up to $2.0-5.0 \mathrm{ml}$ of hydrolysis solvent. In practice, about $0.3 \mathrm{ml}$ of solvent was added for the preparation of protein hydrolysates. The basic designs of the vials and tubes are based on the inert-gas flushing instead of vacuum-sealing procedure for the removal of oxygen inside the tubes (Chiou and Wang, 1990). The Reacti-Therm dry block heating system (Pierce 


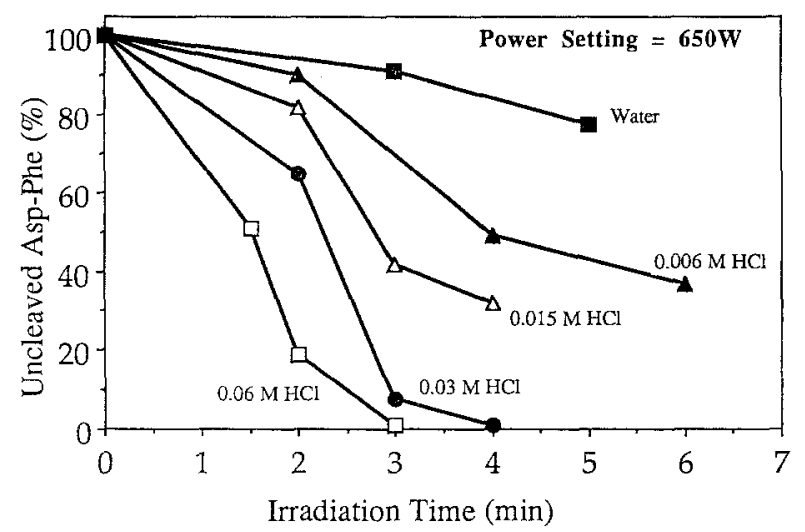

Fig. 1. The effect of solvent acidity on the hydrolysis of peptide bond in dipeptide Asp-Phe. The procedures for microwave irradiation and quantitative analysis of irradiated products are as described in Section 2.2 of Materials and Methods.

Chemical Company, Rockford, Illinois) set at $145^{\circ} \mathrm{C}$ for conventional hydrolysis was also used for comparison. The microwave oven used was a commercially available cooking apparatus without any modification (Tatung microwave oven TMO-1110, Tatung Co., Taipei, Taiwan). The total power of microwaves was $650 \mathrm{~W}$, with 10 power setting starting from $36 \mathrm{~W}$ and operated at a frequency of $2450 \mathrm{MHz}$.

Constant boiling $6 \mathrm{M} \mathrm{HCl}$ in $1 \mathrm{ml}$ ampules was obtained from Pierce. Dipeptides were obtained from Sigma (St. Louis, Missouri). The HPLC system consisted of two Waters Model 6000 pumps, a Waters Model 450 UV detector, and an M-660 solvent programmer. All HPLC-grade solvents were obtained from a local supplier (Alps Chem. Co., Taiwan). The oligopeptides were synthesized with the established methods and purified to homogeneity.

\subsection{General Procedure for Microwave-Irradiated Peptide Hydrolysis}

The peptides (about $1 \mathrm{mg} / \mathrm{ml}$ each) were dissolved in dilute hydrochloric acid, and aliquots of $0.3 \mathrm{ml}$ were transfered to the Teflon vials. The vials were covered with a silicon septum and flushed with nitrogen gas for about $1 \mathrm{~min}$. Afterward, the vials were placed in the center of a microwave oven and irradiated for a specified time at a desired power setting. After irradiation, the hydrolysates were treated with $o$-phthaldehyde to form fluorescent derivatives and analyzed by reversed-phase HPLC. The column $(4.0 \times 300 \mathrm{~mm}$, SynChropak RP-C $18,6.5 \mu \mathrm{m}$ bead $)$ was used to analyze the cleavage products from

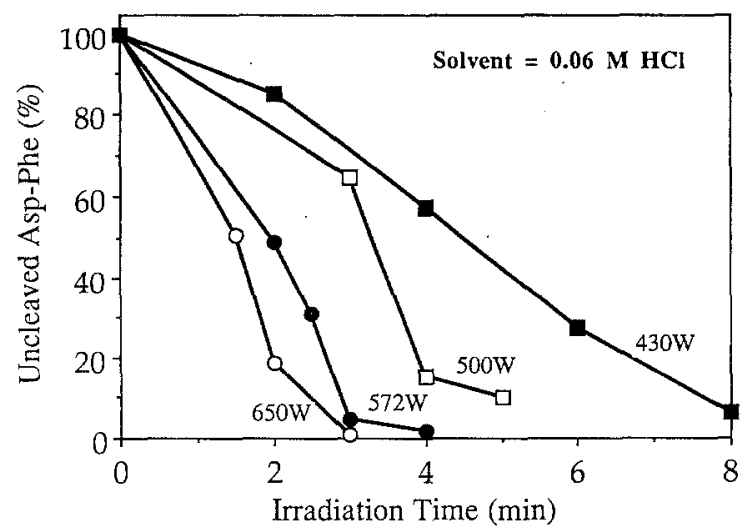

Fig. 2. The effect of input powers of microwave irradiation on the hydrolysis of peptide bond in dipeptide Asp-Phe. The procedures and conditions for microwave irradiation are as described in Materials and Methods.

microwave irradiation under different conditions. The peaks were monitored with a fluorescence detector.

\subsection{Dipeptide Hydrolysis by Conventional Method}

The same peptide solutions as described above were placed in Teflon-Pyrex tubes, flushed with nitrogen gas, and hydrolysis was carried out in a heating block set at $145^{\circ} \mathrm{C}$ for different time periods. The hydrolysates were analyzed by HPLC with the same fluorescent technique described above.

\subsection{Solid-Phase Synthesis of Peptides}

t-Boc-amino acid was attached to the resin (0.6 mmol $\mathrm{Cl}^{-} / \mathrm{g}$ resin) according to the method as described by Gisin (1973). The coupling yield of the amino acid attached to resin was $0.54 \mathrm{mmol} / \mathrm{g}$ resin. The subsequent additions of other t-Boc-amino acids to the solid support were according to the sequences shown in Table II (nonapeptide) and Table III (tetradecapeptide). The final peptides were cleaved from the resin by HF method as follows: (1) $1 \mathrm{~g}$ of peptide resin in $0.2 \mathrm{ml}$ of anisole was poured into the reaction vessel (HF-reaction apparatus, type II, from Peptide Institute). The vessel was cooled in a dry ice-isopropanol bath for $30 \mathrm{~min}$ and evacuated. (2) $10 \mathrm{ml}$ of $\mathrm{HF}$ was charged into the reaction vessel and reacted at $0^{\circ} \mathrm{C}$ for $45 \mathrm{~min}$. (3) The HF was evaporated and residues were washed with ether $(3 \times 30 \mathrm{ml})$ on a sintered glass filter to remove side products. (4) The peptide was separated from resin by washing with $20 \mathrm{ml}$ of 


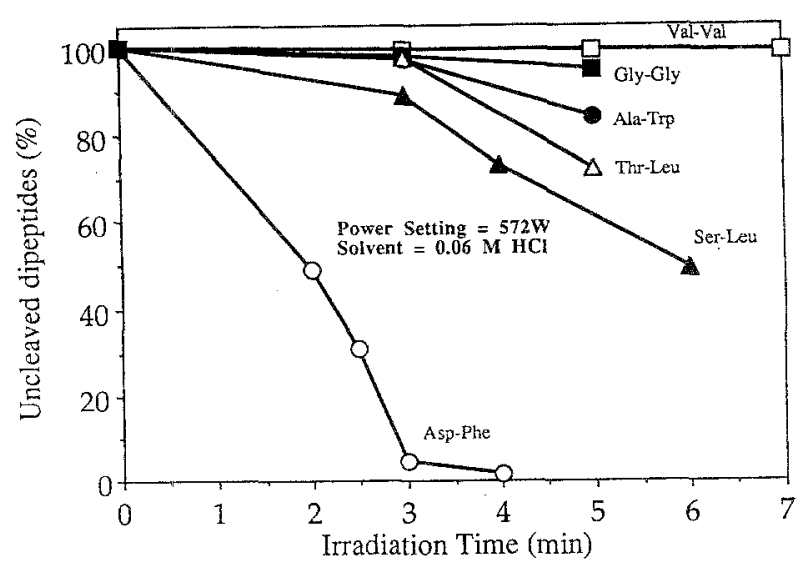

Fig. 3. Time-course study of peptide-bond cleavage in different dipeptides by microwave irradiation in $0.06 \mathrm{M} \mathrm{HCl}$ and an input power of $572 \mathrm{~W}$.

0.1 M TFA three times and the combined TFA solution lyophilized to give the crude peptides.

The crude peptides thus obtained were purified by preparative HPLC. They all gave a single peak on reversed-phase HPLC, and amino acid analysis also indicated compositions consistent with the desired synthesized peptides.

\section{RESULTS AND DISCUSSION}

The dipeptide Asp-Phe was first used to establish the effect of solvent acidity on the peptide-bond hydrolysis. The reaction was performed at five different concentrations of hydrochloric acid $(0.06 \mathrm{M}, 0.03 \mathrm{M}$, $0.015 \mathrm{M}$, and $0.006 \mathrm{M})$ and water $(p \mathrm{H} 7.0)$, respectively, with an input power of $650 \mathrm{~W}$, and the time course of peptide-bond hydrolysis was monitored by HPLC analysis of uncleaved dipeptide. The hydrolysis of the peptide bond was completed within $3 \mathrm{~min}$ in $0.06 \mathrm{M} \mathrm{HCl}$ and $4 \mathrm{~min}$ in $0.03 \mathrm{M} \mathrm{HCl}$ (Fig. 1). On the other hand, the hydrolysis of peptide bond in neutral aqueous solution was less than $15 \%$ after 4 min microwave irradiation. These observations emphasized the important role of specific acid catalysis in the reaction of peptide hydrolysis.

Microwave energy irradiated on the samples in various liquid media is lost or absorbed to the samples by two mechanisms: ionic conduction and dipole rotation. These two effects take place simultaneously to account for the phenomenon of rapid heating associated with many practical applications of microwave heating (Jassie and Kingston, 1988; Neas and Collins, 1988). Because the inherent hazard of explosion due

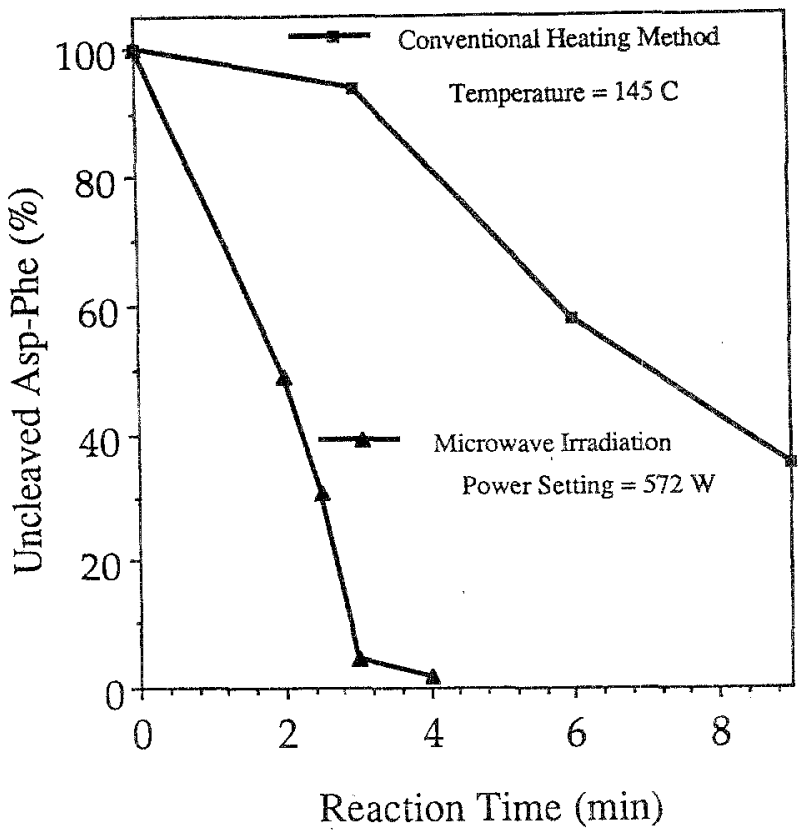

Fig. 4. Comparison of the rate of peptide-bond cleavage in AspPhe using microwave irradiation and conventional heating at $145^{\circ} \mathrm{C}$ in $0.06 \mathrm{M} \mathrm{HCl} \mathrm{solvent.}$

to a rapid pressure buildup caused by microwave irradiation was well known (Chen et al., 1990; Chiou and Wang, 1990), a systematic study of suitable reaction conditions to find an appropriate input power for the complete hydrolysis of peptide bonds without overheating is highly desirable. Four different input powers were chosen and the reactions were carried out in $0.06 \mathrm{M}$ hydrochloric acid to find the optimal condition for complete hydrolysis of the peptide bond in Asp-Phe (Fig. 2). It was found that an input power of $572 \mathrm{~W}$ or $650 \mathrm{~W}$ is very suitable for the hydrolysis

Table I. Reaction Half-Life Times of Peptide-Bond Cleavage in Various Conditions

\begin{tabular}{cccc}
\hline $\begin{array}{c}\text { Tested } \\
\text { dipeptides }\end{array}$ & $\begin{array}{c}0.015 \mathrm{M} \mathrm{HCl} \\
\text { at } 110^{\circ} \mathrm{C}^{\prime}\end{array}$ & $\begin{array}{c}0.06 \mathrm{M} \mathrm{HCl} \\
\text { by microwave }\end{array}$ & $\begin{array}{c}0.06 \mathrm{M} \mathrm{HCl} \\
\text { at } 145^{\circ} \mathrm{C}\end{array}$ \\
\hline Asp-Lys & $228^{6}$ & 2.6 & 8.5 \\
Lys-Asp & 165 & 4.3 & 8.0 \\
Asp-Phe & 130 & 2.0 & 5.2 \\
Asp-Asp & & 3.0 & 7.5 \\
Asp-Glu & & 2.5 & 8.0 \\
Asp-Ala & & 2.3 & 3.0 \\
Ala-Asp & 108 & 2.2 & 9.8 \\
Gly-Asp & & 1.6 & 12.0 \\
\hline
\end{tabular}

"The concentrations of amino acids released were determined by HPLC analysis (RP-C 18 column).

${ }^{b}$ Time required for $50 \%$ hydrolysis $(\mathrm{min})$. 


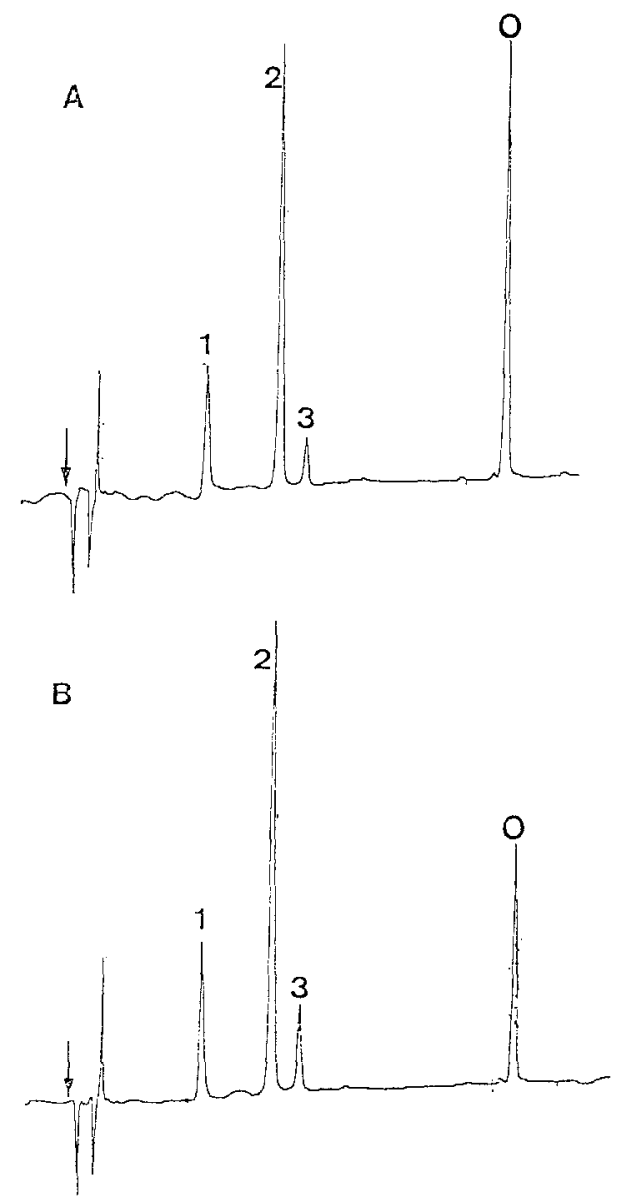

Fig. 5. HPLC analysis of peptide fragments of the synthetic peptide Ala-Glu-Phe-Ala-Asp-Pro-Ser-Leu-Gly by microwave irradiation in $0.06 \mathrm{M} \mathrm{HCl}$ under conditions of different input power and irradiation time. (A) $143 \mathrm{~W}, 3 \mathrm{~min}$; (B) $72 \mathrm{~W}, 6 \mathrm{~min}$. Conditions for reversed-phase HPLC: RP-C 18 column; A 30 min linear gradient of 11-23\% acetonitrile in water containing $0.1 \% \mathrm{TFA}$; and Peaks monitored by UV absorbance at $214 \mathrm{~nm}$. The peaks 1,2 , and 3 were identified by amino acid analysis as shown in Table II. Peak $O$ and arrow indicate the uncleaved peptide and starting point for sample injection, respectively.

reaction and the peptide bonds can be hydrolyzed within 3 min safely.

In order to compare the relative susceptibility of the peptide bonds in various dipeptides as compared to that of Asp-Phe, five dipeptides Ala-Trp, Val-Val, Gly-Gly, Thr-Leu, and Ser-Leu were reacted under the identical irradiated conditions in $0.06 \mathrm{M} \mathrm{HCl}$ and $572 \mathrm{~W}$ input power (Fig. 3). The peptide bond of Asp-Phe was completely hydrolyzed within $4 \mathrm{~min}$, whereas all other non-Asp containing dipeptides remained at least $75 \%$ intact. The optimized condition of inducing higher than $95 \%$ peptide cleavage in AspPhe while keeping more than $90 \%$ peptide bonds
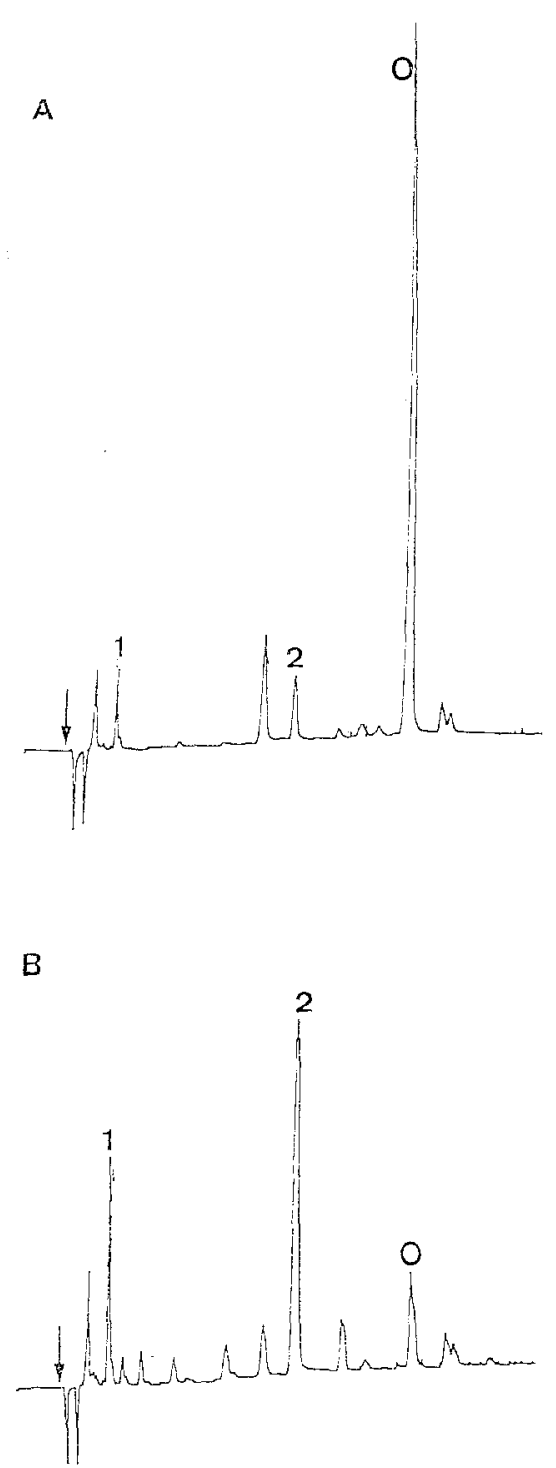

Fig. 6. HPLC analysis of peptide fragments of the synthetic peptide Gly-Phe-Lys-Phe-Ser-Phe-Glu-Phe-Gly-Asp-Phe-AlaLeu-Gly by microwave irradiation in $0.06 \mathrm{M} \mathrm{HCl}$ under conditions of different input power and irradiation time. (A) $215 \mathrm{~W}, 3 \mathrm{~min}$; (B) $286 \mathrm{~W}, 4.5 \mathrm{~min}$. Conditions for HPLC are the same as Fig. 5. The peaks 1 and 2 were identified by amino acid analysis as shown in Table III. Peak $\mathrm{O}$ and arrow indicate the uncleaved peptide and starting point for sample injection, respectively.

intact in other dipeptides was found to be that of the milder condition for $3 \mathrm{~min}$ irradiation. It is noteworthy that under this reaction condition the peptide bond and Trp residue in Ala-Trp dipeptide remained more or less intact in contrast to the complete peptide hydrolysis of Asp-Phe employing 3 min microwave irradiation. It is well known that Trp residues in most proteins are totally destroyed under the regular $6 \mathrm{M}$ 
$\mathrm{HCl}$ hydrolysis. This observation may be applied to the sequencing study of Trp-containing peptides to prevent the Trp from decomposition by using the rapid microwave heating under mild acid and short irradiation.

Figure 4 shows the comparison of time courses between peptide-bond hydrolysis in Asp-Phe by conventional method $\left(145^{\circ} \mathrm{C}\right.$, heating block) and microwave irradiation (power $572 \mathrm{~W}$ ). It is evident that the hydrolysis by microwave irradiation is much faster than that by conventional heating method as judged by the slopes shown in Fig. 4. The drastic difference in the reaction profiles may be explained by a more rapid energy transfer in microwave irradiation than conventional heating. In the microwave-irradiated reactions, all microwave energy is adsorbed by the solution since Teflon vessels used are almost microwave transparent. The temperature of the reaction solution was determined to be about $140-155^{\circ} \mathrm{C}$ and that of the vessel about $40-50^{\circ} \mathrm{C}$ after $2-3 \mathrm{~min}$ irradiation. We have also compared the hydrolysis times required for 8 different Asp-containing dipeptides using three different protocols (Table I). In general, the time needed for complete hydrolysis by microwave irradiation is only about $1 / 6$ to $1 / 3$ that of the conventional heating at $145^{\circ} \mathrm{C}$.

Two Asp-containing peptides Ala-Glu-PheAla-Asp-Pro-Ser-Leu-Gly and Gly-Phe-Lys-PheSer-Phe-Glu-Phe-Gly-Asp-Phe-Ala-Leu-Gly were synthesized by the standard solid-phase method and purified to homogeneity as judged by both TLC and HPLC. The time-course studies of the cleavage of these peptides were followed by HPLC (Figs. 5 and 6) and amino acid analysis (Tables II and III). From the composition data of the cleaved fragments, it was clearly indicated that the peptides were cleaved

Table II. Amino Acid Analysis of Tested Synthetic Peptide AlaGlu-Phe-Ala-Asp-Pro-Ser-Leu-Gly and Its Peptide Fragments Isolated by HPLC After Cleavage by Microwave Irradiation in 0.06 м Hydrochloric Acid

\begin{tabular}{lcccc}
\hline & Uncleaved & \multicolumn{3}{c}{ Isolated fragments } \\
\cline { 4 - 5 } $\begin{array}{c}\text { Amino acid } \\
\text { residues }\end{array}$ & $\begin{array}{c}\text { synthetic } \\
\text { peptide }\end{array}$ & Peak 1 & Peak 2 & Peak 3 \\
\hline Ala (2) & 2.00 & & 2.00 & 2.00 \\
Glu (1) & 1.07 & & 1.02 & 1.00 \\
Phe (1) & 0.99 & & 1.00 & 0.98 \\
Asp (1) & 1.04 & & 1.00 & \\
Pro (1) & 1.04 & 0.98 & & \\
Ser (1) & 0.73 & 0.75 & & \\
Leu (1) & 1.05 & 1.04 & & \\
Gly (1) & 1.07 & 1.00 & & \\
\hline
\end{tabular}

Table III. Amino Acid Analysis of Synthetic Peptide Gly-PheLys-Phe-Ser-Phe-Glu-Phe-Gly-Asp-Phe-Ala-Leu-Gly and Its Peptide Fragments Isolated by HPLC After Cleavage by Microwave Irradiation in $0.06 \mathrm{M} \mathrm{HCl}$

\begin{tabular}{|c|c|c|c|}
\hline \multirow{2}{*}{$\begin{array}{l}\text { Amino acid } \\
\text { residues }\end{array}$} & \multirow{2}{*}{$\begin{array}{l}\text { Uncleaved } \\
\text { synthetic } \\
\text { peptide }\end{array}$} & \multicolumn{2}{|c|}{ Isolated fragments } \\
\hline & & Peak 1 & Peak 2 \\
\hline Leu (1) & 1.01 & 0.96 & \\
\hline Ala (1) & 0.95 & 0.91 & \\
\hline Gly (3) & 3.00 & 1.00 & 2.00 \\
\hline Phe (5) & 4.86 & 0.96 & 3.89 \\
\hline Lys (1) & 1.01 & & 0.99 \\
\hline $\operatorname{Ser}(1)$ & 0.75 & & 0.71 \\
\hline Glu (1) & 1.07 & & 1.04 \\
\hline Asp (1) & 1.30 & & \\
\hline
\end{tabular}

specifically at both ends of aspartic acid along the peptides. In Schemes I and II, we show the cleavage sites and the sequences of the resulting fragments. It is noteworthy that the peptide bonds of Asp-Pro and

Ala-Glu-Phe-Ala-Asp-Pro-Ser-Leu-Gly

$$
\text { hydrolysis }
$$

$$
\begin{aligned}
& \text { Ala-Glu-Phe-Ala-Asp }+ \text { Pro-Ser-Leu-Gly } \\
& \text { (Peak 2) } \\
& \qquad \text { further hydrolysis }
\end{aligned}
$$

$$
\begin{gathered}
\text { Ala-Glu-Phe-Ala + Asp } \\
\text { (Peak 3) }
\end{gathered}
$$

Scheme 1. Proposed hydrolytic pathway of the synthetic peptide Ala-Glu-Phe-Ala-Asp-Pro-Ser-Leu-Gly by microwave irradiation in $0.06 \mathrm{M} \mathrm{HCl}$; three fragments (Peaks 1, 2, and 3) were detected by HPLC.

Gly-Phe-Lys-Phe-Ser-Phe-Glu-Phe-Gly-Asp-Phe-Ala-Leu-Gly

Gly-Phe-Lys-Phe-Ser-Phe-Glu-Phe-Gly + Asp +Phe-Ala-Leu-Gly
(Peak 2)

Scheme II. Proposed hydrolytic pathway of the synthetic peptide Gly-Phe-Lys-Phe-Ser-Phe-Glu-Phe-Gly-Asp-Phe-Ala-Leu-Gly by microwave irradiation in $0.06 \mathrm{M} \mathrm{HCl}$; only two fragments (Peaks 1 and 2) were detected by HPLC. 
Ala-Asp are more labile than all other peptide-bond linkages in the first peptide and those of Gly-Asp and Asp-Phe in the second peptide are weaker than other peptide bonds.

In conclusion, a method using microwave irradiation and weak acid have been developed to control the cleavage sites of peptide bonds, especially those bonds connected to aspartic acid residues inside the native peptides and proteins. The method should prove very useful to obtain the defined acid-cleaved peptide fragments of proteins and circumvent the contamination problems inherently associated with microscale purification and sequence analysis of fragments generated from proteolytic enzymes.

\section{ACKNOWLEDGMENTS}

We acknowledge the generous support of Academia Sinica and the National Science Council, Taipei, Taiwan ROC.

\section{REFERENCES}

Chen, S.-T., Chiou, S.-H., Chu, Y.-H., and Wang, K.-T. (1987). Int. J. Peptide Protein Res. 30, 572-576.

Chen, S.-T., Chiou, S.-H., and Wang, K.-T. (1990). J. Chem. Soc. Chem. Commun. 807-808.
Chiou, S.-H., and Wang, K.-T. (1989). J. Chromatogr. 491, 424 431.

Chiou, S.-H., and Wang, K.-T. (1990). In Current Research in Protein Chemistry: Techniques, Structure, and Function (Vilafranca, J. J., ed.) Academic Press, New York, pp. 3-10.

Fernando, L. A., Heavner, W. D., and Gabrielli, C. C. (1986). Anal. Chem. 58, 511-512.

Fischer, L. B. (1986). Anal. Chem. 58, 261-263.

Gisin, B. F. (1973). Helv. Chim. Acta 56, 1476-1482.

Inglis, A. S. (1983). Methods Enzymol. 91, 324-332.

Jassie, L. B., and Kingston, H. M. (1988). In Introduction to Microwave Sample Preparation: Theory and Practice (Jassie, L. B. and Kingston, H. M., eds.) American Chemical Society, Washington, D.C., pp. 1-6.

Kingston, H. M., and Jassie, L. B. (1986). Anal. Chem. 58, 25342541 .

Light, A. (1967). Methods Enzymol. 11, 417-420.

Marcus, F. (1985). Int. J. Peptide Protein Res. 25, 542-546.

Nadkarni, R. (1984). Anal. Chem. 56, 2233-2237.

Neas, E. D., and Collins, M. J. (1988). In Introduction to Microwave Sample Preparation: Theory and Practice (Jassie, L. B. and Kingston, H. M., eds.), American Chemical Society, Washington, D.C., pp. 7-32.

Piszkiewicz, D., Landon, M., and Smith, E. L. (1970). Biochem. Biophys. Res. Commun, 40, 1173-1178.

Schultz, J., Allison, H., and Grice, M. (1962). Biochemistry 1, 694-698.

Schultz, J. (1967). Methods Enzymol. 11, 255-264.

Tsung, C. M., and Fraenkel-Conrat, H. (1965). Biochemistry 4, $793-801$.

Wang, K.-T., Chen, S.-T., and Chiou, S.-H. (1991). In Techniques in Protein Chemistry II (Villafranca, J. J., ed.), Academic Press, New York, pp. 241-247.

Yu, H.-M., Chen, S.-T., Chiou, S.-H., and Wang, K.-T. (1988). J. Chromatogr. 456, 357-362. 